INFO ARTIKEL

Riwayat Artikel:

Diterima

: 01 Januari 2020

Disetujui

: 16 Februari 2020

\title{
PENDIDIKAN
}

\section{PENGARUH MODEL PEMBELAJARAN MIND MAPPING TERHADAP HASIL BELAJAR SISWA KELAS $X$ PADA MATA PELAJARAN GEOGRAFI DI SMA NEGERI 2 KIKIM SELATAN TAHUN PELAJARAN 2018/2019}

\author{
Yanda Nauri ${ }^{1}$, Helfa Septinar ${ }^{2}$, Misdalina ${ }^{3}$ \\ 1-2 Program Studi Pendidikan Geografi, Universitas PGRI Palembang \\ ${ }^{3}$ Program Studi Pendidikan Matematika, Universitas PGRI Palembang \\ (区) Yandanauri02@gmail.com ${ }^{1}$
}

\begin{abstract}
ABSTRAK
Rumusan masalah dalam penelitian ini adalah pengaruh model Pembelajaran Mind-Mapping terhadap Hasil Belajar siswa kelas X pada mata pelajaran geografi di SMA Negeri 2 Kikim Selatan. Penelitian ini bertujuan untuk mengetahui pengaruh model pembelajaran Mind Mapping terhadap Hasil Belajar siswa kelas X pada mata pelajaran geografi di SMA Negeri 2 Kikim Selatan. Metode yang digunahkan adalah metode pendekatan kuantitatif dengan metode eksprimen. Populasi dalam penelitian ini adalah kelas X SMA Negeri 2 Kikim Selatan. Pengambilan sampel menggunakan teknik sempel random sehingga diperoleh kelas $\mathrm{XIPS}_{1}$ sebagai kelas eksperimen dan kelas XIPS $2_{2}$ sebagai kelas kontrol. Teknik pengumpulan data menggunakan teknik tes. Teknik analisis data menggunakan uji hipotesis dengan uji-t, diperoleh $t_{\text {hitung }}$ yaitu 6,369, dibandingkan dengan $\mathrm{t}_{\text {tabel }} 1,683$ untuk $\mathrm{dk}=\mathrm{n} 1+\mathrm{n} 2-2=60$ dengan taraf signifikan $5 \%$ dengan demikian $t_{\text {hitung }}>t_{\text {tabel. }}$. Berarti Ha diterima dan Ho ditolak. Maka dapat disimpulkan bahwa terdapat pengaruh model pembelajaran Mind Mapping terhadap hasil belajar siswa kelas X pada mata pelajaran geografi di SMA Negeri 02 Kikim Selatan. Berdasarkan hasil analisis data tes dapat disimpulkan ada pengaruh yang signifikan antara model pembelajaran Mind Mapping terhadap Hasil Belajar siswa kelas X pada mata pelajaran geografi di SMA Negeri 2 Kikim Selatan.
\end{abstract}

Kata Kunci : Model Pembelajran Mind Mapping dan Hasil Belajar Geografi.

\section{PENDAHULUAN}

Omar Muhamad Ath-Thaumy Asy-Syaibany, mengartikan pendidikan sebagai perubahan yang diinginkan dan diusahkan oleh proses pendidikan, baik pada tataran tingkah laku individu maupun pada tataran kehidupan sosial, serta pada tataran relasi dengan alam sekitar: atau pengajaran sebagai aktivitas asasi, dan sebagai proporsi di antara profesi - profesi dalam masyarakat. Pendidikan memfokuskan perubahan tingkah laku manusia, yang konotasinya pada pendidikan etika. Di samping itu, pendidikan juga menekankan aspek produktivitas dan kreatifitas manusia sehingga mereka dapat berperan serta berprofesi dalam kehidupan masyarakat (Salahudin, 2011:20).

Guru sering kali tidak menerapkan pembelajaran yang menarik sehingga guru hanya mengajar dengan metode yang mudah bagi mereka. Yaitu metode ceramah dalam metode ceramah guru hanya menjelaskan secara lisan. Berdampak pada hasil belajar siswa yang semakin hari nilainya turun, siswa tidak tertarik dalam kegiatan belajar mengajar karena mereka hanya menerima informasi, mengingat, menghapal, dan ditambah lagi fasilitas yang ada di sekolahan tidak lengkap. Sarana tidak lengkap seperti fasilitas belajar berupa infokos yang ada disekolah hanya 
ada satu. Guru harus bergantian untuk menggunakan infokos tersebut. Hingga guru lebih dominan menggunakan metode ceramah, akibatnya siswa terasa bosan. Bukan kah guru adalah pusat belajar dari siswa karena guru mentransfer ilmu kepada siswa jadi siswa hanya menerima informasi dari guru tersebut. Sebagai seorang guru kita harus memecahkan masalah tentang rendahnya hasil belajar siswa.

Salah satu cara mengatasinya yaitu menerapkan model pembelajaran yang dapat menciptakan suasana yang menyenangkan, di mana belajar sambil bermain sehingga siswa merasa tidak tegan. Yang dapat membuat siswa aktif sehingga dapat meningkatkan hasil belajar siswa. Salah satu caranya yaitu model pembelajaran yang digunakan oleh guru adalah model pembelajaran mind mapping yang dapat mendorong siswa untuk lebih aktif dalam proses belajar. Tujuan penelitian ini adalah untuk mengetahui Apakah ada Pengaruh Model Pembelajaran Mind Mapping Terhadap Hasil Belajar Siswa Pada Kelas X Pada Mata Pelajaran Geografi di SMA Negeri 02 Kikim Selatan tahun ajaran 2018/2019.

Model Pembelajaran adalah suatu perencanaan atau pola yang dapat kita gunakan untuk mendesain pola yang dapat kita gunakan untuk mendesain pola-polamengajar tatap muka di dalam kelas atau tutorial (Trianto, 2014:52) Dan juga Model pembelajaran dapat diartikan sebagai cara yang digunakan untuk mengimplementasikan rencana sudah disusun dalam bentuk kegiatan nyata dan praktis untuk mencapai tujuan pembelajaran (Khosim, 2017:5). Menurut Joyce dan Weil berpendapat bahwa model pembelajaran adalah suatu rencana atau pola yang dapat digunakan untuk membentuk kurikulum (rencana pembelajaran jangka panjang), merancang bahanbahan pembelajaran, dan membimbing pembelajaran dikelas atau yang lain (Rusman, 2012:133).

Mind mapping dapat diartikan peta pikir yang lebih jelas, mendalam, dan menarik daripada rangkuman. Sebab dalam peta pikiran digunakan teknik grafis dan ruang (baik berupa gambar dan simbol) serta warna untuk menandai ide-ide dalam pikiran (Suroso, 2010: 85). Konsep Mind Mapping asal mulanya diperkenalkan oleh Tony Buzan tahun 1970-an. Model pembelajaran mind mapping adalah model pembelajaran yang mempelajari konsep atau teknik mengingat sesuatu dengan bantuan mind map (menggunakan peta konsep, pencatatan materi belajar dituangkan dalam bentuk diagram yang membuat simbol, kode, gambar, dan warna yang saling berhubungan) sehingga kedua bagian otak manusia dapat digunakan secara maksimal (Zarkasyi, 2015:76).

Mind Mapping adalah pembelajaran yang sangat cocok untuk mereview pengetahuan awal siswa. Sintaknya adalah: informasi kompetensi, sajian permasalahan terbuka, siswa berkelompok untuk menanggapi dan membuat berbagai alternatif jawaban. Presentasi hasil diskusi kelompok, siswa dapat membuat kesimpulan dari hasil setiap kelompok, evaluasi dan refleksi (Ngalimun, 2017:348).

Langkah-langkah dalam pembelajaran Mind Mapping, terdapat enam langkah yang harus dilakukan dalam proses pembelajaran (Zarkasyi, 2015:76) yaitu :

1. Guru menyampaikan kompetensi yang ingin dicapai.

2. Guru menyampaikan materi pelajaran.

3. Membentuk kelompok yang anggotanya 2-3 orang.

4. Tiap kelompok mengiventarisasi/ mencatat poin-poin penting dari materi yang disampaikan.

5. Tiap kelompok menyajihkan kembali materi yang telah disampaikan guru dalam bentuk peta konsep (mind map) berupa bagan atau diagram.

6. Perwakilan beberapa kelompok mempresentasikan peta konsep yang dibuat.

\section{METODOLOGI PENELITIAN}

Penelitian ini akan dilakukan di SMA Negeri 2 Kikim Selatan. yang berlokasi Di Jalan Desa Nanjungan Kec. Kikim Selatan Kabupaten Lahat. Adapun waktu penelitian akan dilaksanakan pada semester ganjil tahun pelajaran 2019/2020. 
Penelitian ini menggunakan pendekatan kuantitatif dengan metode eksprimen. Populasi dalam penelitian ini adalah seluruh kelas X SMA Negeri 2 Kikim Selatan. Pengambilan sampel menggunakan teknik sempel random sehingga diperoleh kelas $X I P S_{1}$ sebagai kelas eksperimen dan kelas $X I P S_{2}$ sebagai kelas kontrol. Sebelum instrumen penelitian dapat digunakan kepada sampel, maka diteliti terlebih dahulu divalidasikan kepada siswa. melalui uji coba. Dari hasil ujicoba, dihitung validitas, reliabilitas,

\section{HASIL DAN PEMBAHASAN}

Penelitian ini dilaksanakan di SMA dengan sampel penelitian ada dua kelas yaitu kelas $X$ IPSI $_{1}$ yang berjumlah 31 siswa sebagai kelas eksperimen dan kelas $X I P S_{2}$ yang berjumlah 31 siswa sebagai kelas kontrol. Setelah 3 kali pertemuan maka peneliti memberikan tes akhir kepada siswa baik dikelas eksprimen maupun kelas kontrol. Hasil yang dapat bahwa nilai ratarata kelas eksprimen yaitu 76,45 . Sedangkan kelas kontrol nilai rata-rata 61,29 .

Hasilnya lebih tinggi nilai eksprimen yang menggunahkan model mind mapping dari pada kelas kontrol yang menggunahkan model konvensional. Hasilnya terlihat pada gambar dibawah yaitu total nilai, rata-rata, tertinggi dan nilai terendah, baik kelas eksprimen maupun kelas kontrol dapat dilihat pada gambar 1 dan 2 .

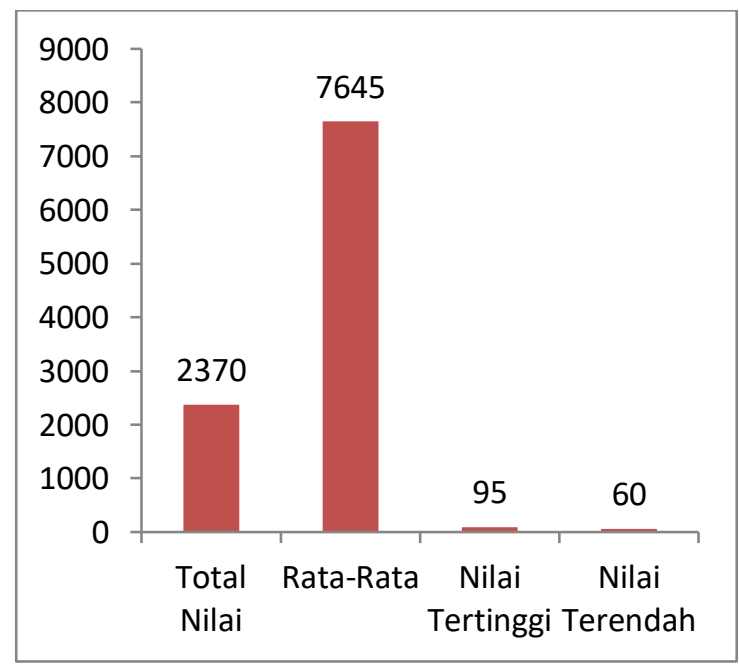

Gambar 1. Grafik Hasil Nilai Eksprimen

(Sumber: Analisis Data, 2019)

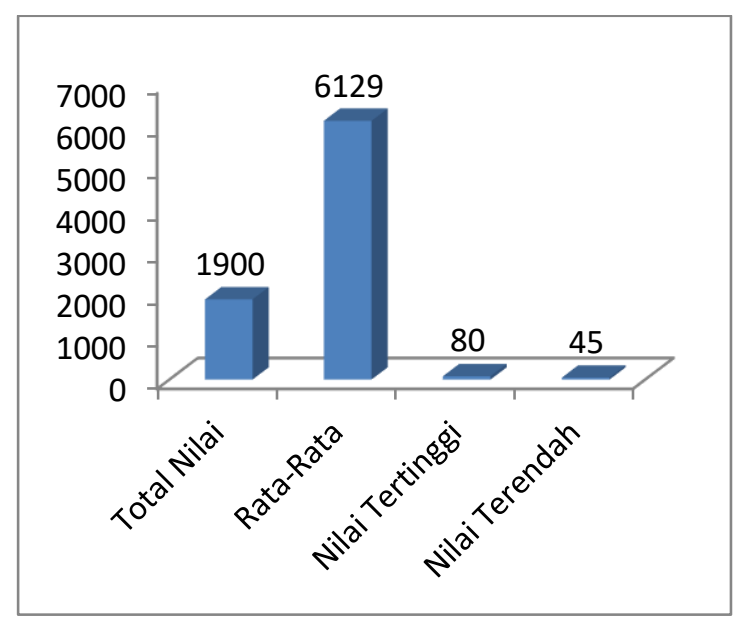

Gambar 2. Grafik Hasil Nilai Kontrol

(Sumber : Analisis Data, 2019)

Berdasarkan hasil yang telah diperoleh dari penelitian, menunjukkan bahwa model pembelajaran mind mapping atau kelas eksprimen yang diberikan perlakuan kelompok memiliki nilai rata-rata yang lebih tinggi dibandingkan dengan nilai rata-rata kelas kontrol yang tidak diberi perlakuan dengan model pembelajaran konvensional.

Model pembelajaran mind mapping Menurut Shoimin (2014: 105), "Model pembelajaran mind mapping adalah model pembelajaran yang meminta siswa untuk membuat mind map (peta pikiran), sehingga memungkinkan siswa mengidentifikasi dengan jelas dan kreatif apa yang telah dipelajari atau apa yang tengah direncanakan". Pada model ini siswa diminta kreatif dalam menggambar supaya mudah diingat dalam materi tersebut. Dalam strateginya teknik pemanfaatan keseluruhan otak untuk mencatat dengan cara mengelompokkan materi yang dipelajari agar lebih kreatif dan efektif untuk mengingat materi pelajaran, dan dalam menggambar inilah siswa tidak mengalami kejenuhan dalam belajar sehingga siswa tertarik dalam belajar.

Dalam proses kegiatan belajar pada penelitian ini, siswa dibagi menjadi 6 kelompok dimana masing-masing kelompok beranggotakan 4 . Setelah siswa duduk dengan kelompoknya masing-masing peneliti membagikan soal kepada siswa untuk di diskusikan oleh siswa. Pada tahap ini siswa mulai mengorganisasikan ide-ide mereka 
untuk memahami masalah yang terdapat pada soal yang diberikan peneliti seperti tentang apa yang diketahui dan apa yang ditanyakan dengan bimbingan guru. Pada tahap ini kelompok siswa dituntun dalam menyelesaikan permasalahan yang dihadapi.

Selanjutnya setelah siswa memahami masalah siswa memikirkan kembali, mendalami dan menggali informasi yang sudah didapat dan dilaksanakan dalam kegiatan kelompok siswa. Sehingga pada tahap inilah siswa menyusun rencana penyelesaian masalah dan melaksanakan penyelesaiannya dengan bimbingan peneliti. Dari tahapan-tahapan inilah siswa yang tadinya pasif dapat menjadi lebih aktif hal ini dikarenakan siswa melakukann diskusi bersama dengan kelompok belajarnya. Selain itu siswa lebih mampu untuk mengerjakan permasalahan yang ada dengan bantuan teman sekelompok. Setelah siswa selesai mengerjakan soal yang diberikan peneliti, peneliti membimbing siswa untuk melakukan pengecekan kembali hasil diskusi yang telah diperoleh dan mempresentasikannya. Pada proses ini siswa mempresentasikan hasil diskusi yang dapat memberikan tanggapan serta kesimpulan dari masalah tersebut.

Dilihat dari hasil perhitungan menggunakan uji hipotesis dengan uji $t$, diperoleh $t_{\text {hitung yaitu }}$ 6,369 , dibandingkan dengan $t_{\text {tabel }} 1,683$ untuk $\mathrm{dk}$ $=\mathrm{n} 1+\mathrm{n} 2-2=60$ dengan taraf signifikan 5\% dengan demikian $t_{\text {hitung }}>t_{\text {tabel. }}$ Berarti Ha diterima dan Ho ditolak .Maka dapat disimpulkan bahwa terdapat pengaruh model pembelajaran mind mapping terhadap hasil belajar siswa kelas X pada mata pelajaran geografi di SMA Negeri 02 Kikim Selatan. Hal ini sesuai dengan hasil penelitian Marcy (2017:173) yaitu dimana hasil tes model pembelajaran mind mapping peserta didik nilai rata-rata 87.56. dalam hal ini metode ini patut dipertahankan.

\section{SIMPULAN}

Berdasarkan data hasil pengujian hipotesis, maka dapat disimpulkan bahwa terdapat pengaruh model pembelajaran mind mapping terhadap hasil belajar siswa kelas X pada mata pelajaran geografi di SMA Negeri 2 Kikim Selatan.

\section{DAFTAR PUSTAKA}

Salahudin, Anas. (2011). Filsafat Pendidikan. Bandung: cv Pustaka Media.

Marcy, Anastasia. (2017). Pengaruh Model Pembelajaran Mind Mapping terhadap Hasil Belajar Siswa. Jurnal Kajian Pendidikan Matematika. Vol 02 (02), 173-182.

Khosim, Noer. (2017). Model-Model pembelajaran, Jakarta: Suryamedia Publishing.

Ngalimun. (2017). Strategi Pembelajaran di Lengkapi Dengan 65 Model Pembelajaran Yogyakarta: Parama Ilmu Yogyakarta.

Rusman. (2012). Model-model Pembelajaran Jakarta: Raja Grafindo persada.

Shoimin, Aris. (2014). Model Pembelajaran Inovatif dalam Kurikulum 2013. Jakarta: Ar-Ruzz Media

Trianto. (2014). Model Pembelajaran Terpadu: Konsep strategi, dan Implementasinya dalam Kurikulum Tingkat Satuan Pendidikan: Jakarta: Bumi Aksara.

Suroso. (2010). Smart Brain: Metode dan Pembelajaran. Lombok: Holistica.

Zarkasyi, Wahyudin. (2015). Penelitian Matematika. Bandung: Reflika Aditama 